The Social Sciences 14 (2): 55-67, 2019

ISSN: $1818-5800$

(C) Medwell Journals, 2019

\title{
External Debt and Economic Growth: An Impact Analysis
}

\author{
${ }^{1}$ Charles O. Manasseh, ${ }^{2}$ Felicia C. Abada, ${ }^{3}$ Jonathan E. Ogbuabor, ${ }^{4}$ Aja Ebeke Egele, \\ ${ }^{3}$ Chinasa E. Urama, ${ }^{1}$ Okoro E.U. Okoro and ${ }^{1}$ Josaphat U.J. Onwumere \\ ${ }^{1}$ Department of Banking and Finance, University of Nigeria, Enugu Campus, Nigeria \\ ${ }^{2}$ School of General Studies, Social Science Unit, University of Nigeria, Nsukka, Nigeria \\ ${ }^{3}$ Department of Economics, University of Nigeria, Nsukka, Nigeria \\ ${ }^{4}$ Department of Marketing, Ebonyi State University, Abakaliki, Nigeria
}

\begin{abstract}
This study empirically investigate the impact of external debt on economic growth using annual time series data from 1970-2015 and linear regression model for the estimation. The results show a positive and significant external debt impact on economic growth. In addition, further inquiries on the extent of structural adjustment programmes on growth show that growth in RGDP increased by $28.3 \%$ in the post-SAP era more than the pre-SAP era. The study, therefore, concludes that external debt has made positive contribution to the economic growth within the periods of the study in Nigeria. Hence, from the study's findings, we recommend that external debt should only be sourced for high priority projects like infrastructural development to driven the private sector economic economy. More so, the Nigerian government should also create good business environment that can promote investor's confidence to attract new business opportunities for more domestic and Foreign investment inflows to the country.
\end{abstract}

Key words: External debt, economic growth, analysis, economic growth, adjustment, investor's

\section{INTRODUCTION}

The amount of indebtedness in the developing world has increased over the past few years and the ability of most of those economies to service their external debt obligations has been weak due to unsustainable buildup inherent in most of these countries. Though, external debt is considered a substantial source of income to promote capital intensive investment for the purpose of encouraging production. But the huge economic problems that characterize developing economies have turned the attention of many government authorities to external debt as the only policy option available to address every little economic issue which ought not to be. This attitude has led to the increased borrowing habit amongst the developing nations. However, regardless of the intention behind the increase in indebtedness of most of the developing countries like Nigeria, it has been pointed that over reliance on external debt could deter growth if not properly monitored. Therefore, high and unattainable levels of external debt could have bad economic consequences. Hence, following the findings by Hassan et al. (2015) if the sequence of continues borrowing is not curbed, the economy will slump further and the resulting increase in external debt service could constraint output growth, due the diversion of funds reasonable to carry on growth process to debt service and this could further trigger increases in unemployment owing to decreases in domestic investment (Arnone et al., 2005; Ajayi and Khan, 2000) fall in reserves, increased exchange rate and consequently increased poverty rate.

Nigeria is the largest economy in Africa but seem to have the highest debt stock when compared to other African peers (Fig. 1). Many governments resort to borrowing in principle to finance public goods and promote the welfare and economic activities of her country. But in the contrary, that has not been the case in Nigeria. While the total debt stock keep increase over the years along with consistent increment in debt servicing, public goods gets deteriorated, affecting the welfare and the economic activities of the country. Though, this may not be a new knowledge because in the discussion of Africa economy, Hicks, Marshall, Chamberlin and Samuelson assert that the major challenge that has engulfed the continent can be attributed to the misrepresentations in the internal operations of the African economies as well as their extreme reliance on the developed countries (Bhatia, 2006). For over three decades, large amount had been borrowed by Nigerian government even at highly privileged interest rates with the expectation to advance the course to development

Corresponding Author: Charles O. Manasseh, Department of Banking and Finance, University of Nigeria, Enugu Campus, Nigeria 


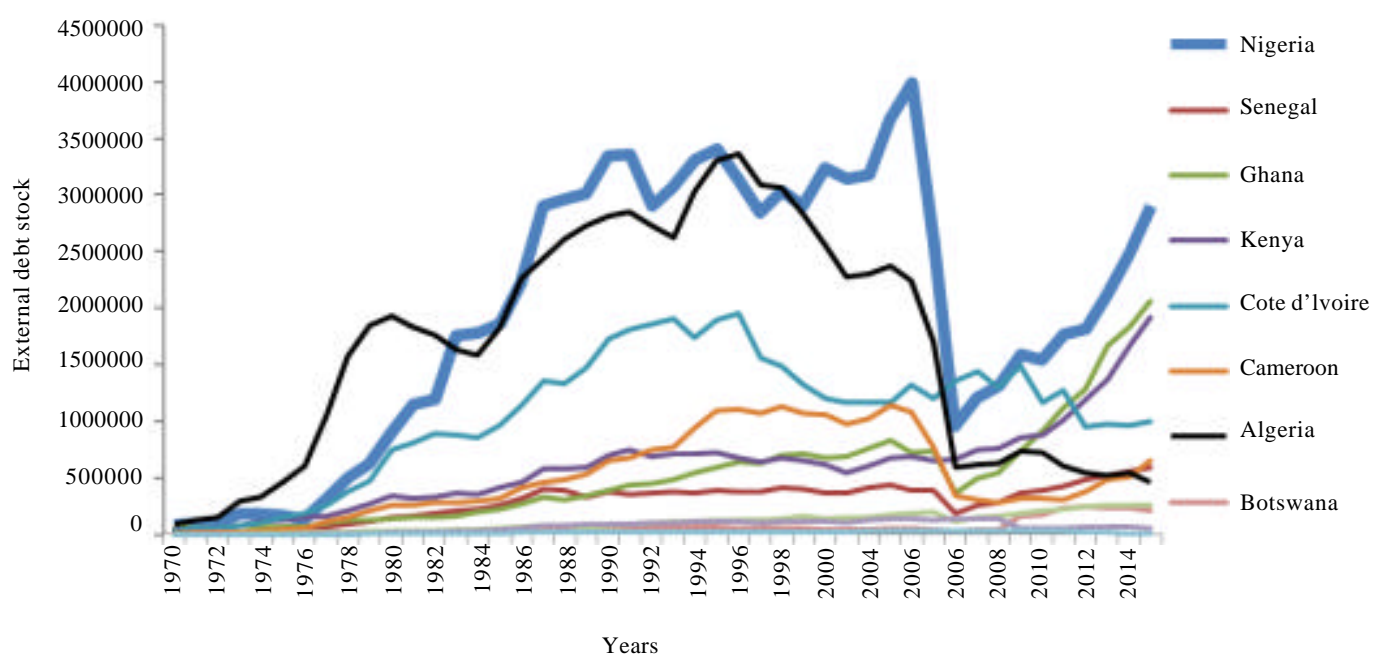

Fig. 1: Total external debt stock in selected Africa countries. World Development Indicators-WDI (2015)

through higher investment and poverty improvement (Hassan et al., 2015). But other than accomplishing the target, unemployment and poverty rate are on the high side amidst excess debt as if that was the main purpose of borrowing.

In line with WDI, Nigeria is among the top most countries in Africa with the highest amount of external debt. Since, 1982 to date, Nigerian external debt has been on the increase compare to other countries in Africa on average. An overview of the movement of total debt stock has shown that in 1982, the total external debt stock was US\$13.1 billion. But due to inability of the government to settle her import bills owing to the accumulation of trade and debt service arrears which escalate market interest rate between 1983 and 1988 , the debt grew rapidly to US\$9.8 billion (Omoh and Ujah, 2014). However, between this periods (i.e., 1983-1988), there was a reconciliation exercise between Nigeria, London and Paris club and the outcome yielded to the reduction of the amount to US\$3.8 billion with an accrued interest of US $\$ 1.0$ billion bringing the total to US\$4.8 in 1998. Thereafter the cancellation within a couple of months, the external debts rose further resulting to total debt outstanding of US\$28.0 billion at the end of 1999 with Paris club constituting the highest share (73.2\%) in 1999. Hence, as at December 2000, the Nigeria's total external debt stock was estimated to be about US\$28.3 billion. Then, from 2001-2005, it grew to about US\$36.7 billion. Thus, after this period, it fell rapidly in 2006 but later increases in an increasing rate from US\$3.7, $\$ 6.363$ billion to US $\$ 13.8$ billion through 2007, 2013 and 2014, respectively (Omoh and Ujah, 2014).

Given the above scenario and the fact that the indebtedness had not yielded significantly to economic growth overtime (Degefe, 1992; Osinubi et al., 2010; Fosu, 1999) many analysts have criticised the high level of indebtedness in Nigeria and call for the reduction on the ground that it will enhance the pursuit of less debt burden threatening growth and improvement in poverty reduction in the country. They argued that external indebtedness affects a country's creditworthiness, investor perceptions and growth process (World Bank, 2016; Audu, 2004), believing that the sum of principal repayments and interest charges actually paid to debtors such as international financial institutions (e.g., World Bank, IMF, etc.,), corporation and private commercial banks could be re-invested into the economy.

According to World Bank (2016), total debt service is somehow related to countrie's ability to possess Foreign exchange amidst the exports of goods, services, primary income and worker's remittances. Nigeria being an oil dependent country whose export of others goods and services are very low have low debt service ability as indicated in Fig. 2. This is due to the country's inability to invest the oil revenue generated into other sectors to promote exports of goods and services and to stimulate the acquisition of Foreign exchange. Therefore, higher possession of Foreign exchange owing to increase in exports of goods and services measure the country's debt service obligations and sustainability. Be that as it may, fast-growing economies and exports oriented countries are likely to sustain higher debt levels (World Bank, 2016). Thus, from the discussion, its crystal clears that the sustainable level of external debt measured with debt to GDP ratio (Fig. 2) and other factors such as Foreign debt to exports ratio and government debt to current fiscal 


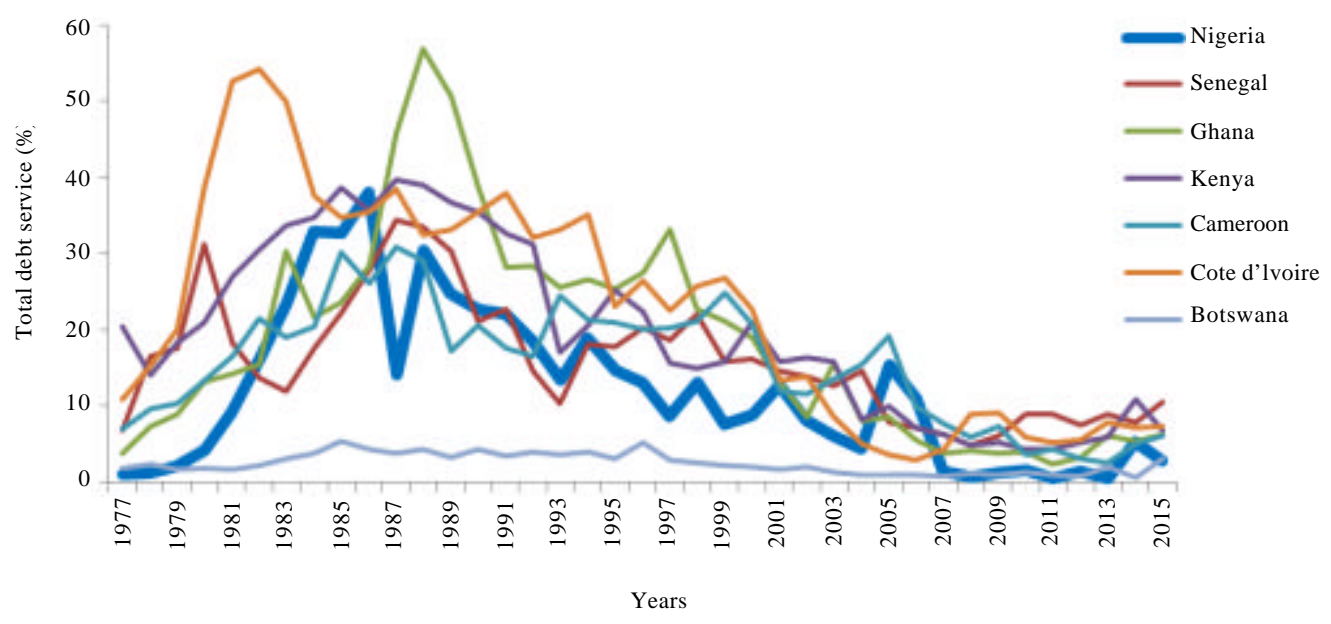

Fig. 2: Total debt service (\% of exports of goods, services and primary income). World Development Indicators-WDI (2015)

revenue ratio have been decreasing in Nigeria compared to countries like Ghana and Senegal. From 1989-2004, the debt to GDP ratio or total debt service (as \% of GDP) decreases at a decreasing rate but appreciated after 2005 due to consolidation policy which promoted the private sector and finally diminishes from 2007-2013.

Furthermore, despite the controversy on the link between external debt and economic growth as well as the inability of the Nigerian government to tap immensely from benefits of external debt, economic growth planning cannot be completely separated from internal and external borrowing. Following the postulate of neoclassical growth theory, debt is directly related to economic growth which simply means that a judicious and optimal use of the amount borrowed is anticipated to drive investment and create more job opportunities (Omoh and Ujah, 2014). Hence, in view of the above conversations, it is pertinent to inquire the extent of external debt impact on economic growth with particular emphasize in pre-sap (1970-1985) and post-SAP (1986-2010) era in Nigeria. We further established the nature of relationship between external debt and economic growth. While studies such as Ariyo (1996), Adams and Bankole (2000), Iyoha (2000) were particularly interested in establishing the impact of external debt on economic growth, they fail to point the channel through which debt could be growth promoting. In addition, to account for the influence of other reforms on external borrowing that have taken place in Nigeria after the post-SAP era (1986-2010), the scope of the study was extended to cover 2015. This enables us to account for the degree of impact of debt on economic growth after post-SAP era in Nigeria.

\section{Review of theoretical and empirical literature}

Review of theoretical literature: Basically, deep investigation had shown two ways a country can grow its economy such as new idea or method in the process of competition (Ellig, 2001) and expansion in the level of investment (i.e., neoclassical growth theory postulated by Solow (1956). According to the later-neoclassical growth theory, rate of saving promotes growth process of an economy. Like the Harrod-Domar Model, neoclassical theory considers saving as a constant fraction of income. This school believed that planned investment is always equal to planned saving (i.e., the net addition to the stock of capital) and that a country could attain economic growth when it increases savings and the level of investment (Fig. 3). Therefore, for a country to record a steady state growth, policies that would support and promotes greater savings should be implemented to improve investment.

While external debt has been opposed to domestic savings as the sure way to promotes economic performance of most developing countries, especially Africa and Nigeria in particular, dual gap theory by Chenery and Strout (1996) viewed external finance as the panacea to attained sustainable growth. According to the theory in an underdeveloped or developing countries, the level of domestic saving is insufficient to finance the needed investment for sustainable growth. The logical representation of this fact remains that external borrowing should be used as a complementary to domestic savings, pointing that the difference between savings and Foreign funds gives a guide on the amount a country can borrow from abroad.

Debt overhang theory: According to Krugman (1988), debt overhang theory postulates that if there is the probability that the future debt will be greater than the repayment ability of a country, the costs of expected 
The Soc. Sci., 14 (2): 55-67, 2019

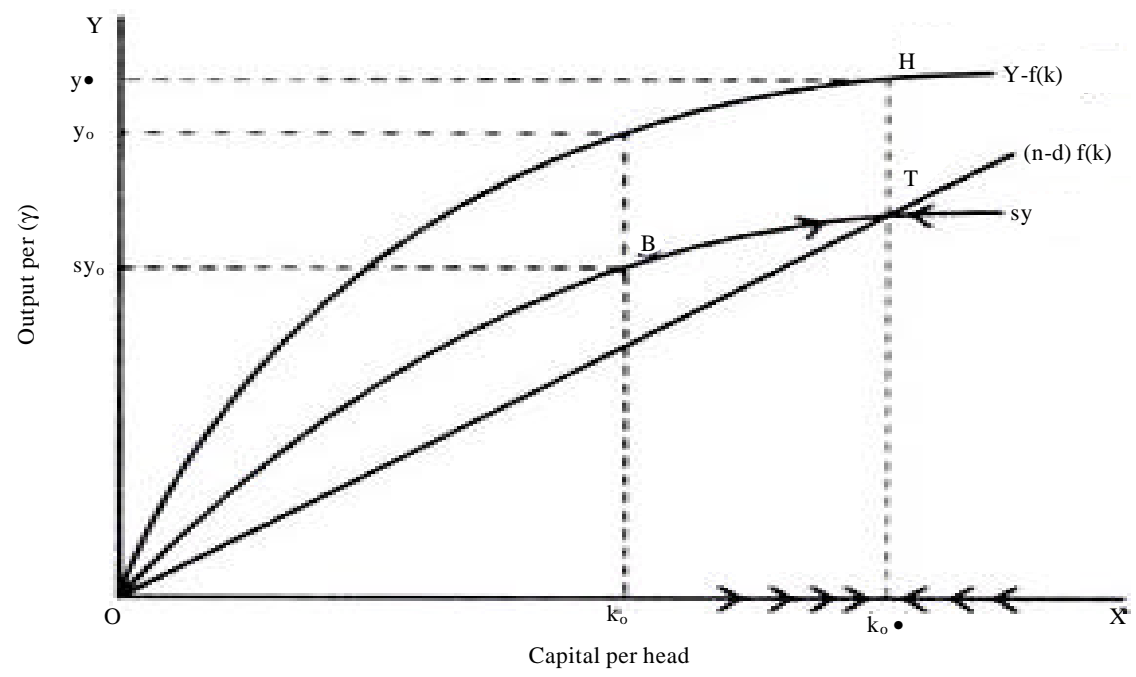

Fig. 3: Growth process and steady state equilibrium. http:/www.yourarticlelibrary.com/economics/neoclassical-theoryof-economic-growth-explained-with-diagrams/38321/

debt-service could inhibit further domestic and Foreign investment. Amidst, the expected gain on the investment over a specified periods of time (normally expressed a percentage of the investment's cost) may be very low to support the economy. Under this circumstance, the borrowers or debtors would benefits insignificantly from any increase in output and exports because a fraction of that increase will be used to service the external debt (Claessens et al., 1996). Invariably, it implies that significant portion of any subsequent economic progress will accrue to the creditor country. In addition, debt overhang theory by Claessens and Diwan (1990) is a situation when the illiquidity effect, the disincentive effect or both are able to hinder economic growth in the absence of concessions by creditors. The stronger the effect becomes, the debtor is said to be on the 'wrong' side of the debt Laffer curve. The debt Laffer curve is the relationship between the amount of debt repayment and the size of debt (Elbadawi et al., 1997). In reference to an aid Laffer curve, Lensink and White (1999) argue that there is a threshold at which more aid is detrimental to growth. A critical analysis of debt overhang theory shows that the scope is much wider such that; the effects do not only affect investment in physical capital but any activity that involves up-front costs incurring intended to increased output in the future (examples of such activities includes, investment in human capital and technology acquisition). Therefore, from the postulate of this theory, debt reduction could promote investment and repayment capacity of the indebted country.

The liquidity constraint theory: The liquidity constraint theory is an extension of debt overhang theory by Cohen
(1993) which proposes that the requirements or debt service payments crowd out investments by reducing funds available for investment in areas such as education, health and infrastructure development which have direct or indirect impact on economic growth. Therefore, crowding out effect arises when there is a decrease in the current debt service that lead to an increase in current investment for any given level of future indebtedness. Thus, Cohen (1993) maintains that this situation can raise expectations for devaluation, leading to capital flight. In the contrary, to curb the negative effect of external debt in an economy, he suggested debt relief as the only way to facilitate economic growth. In that regard, he argued that the freed resources which were tied up in debt servicing could be reallocated to more productive areas. But a look in the details of resource mechanism shows that debt relief alone might not encourage or promote growth to a large extent but other factors such as the degree of the relief, government investment decisions on the freed resources, revenue collection and new borrowing may complementary and as well serve as an incentive to growth. Thus, a reduction in the current debt service may relate to an increase in current investment for any given level of future indebtedness. Supporting the propositions of Cohen (1993) on the suggested positive relationship between reduction in debt service and current level of investment, Cassimon et al. (2008) argued that even in the presence of debt relief to countries facing repayment difficulties, that the freed resources might not create a greater fiscal space to promote investment. In furtherance of this statement, Johansson (2010) pointed that one of the factors that could reduce the impact of debt relief on growth might be moral hazard or adverse 
selection. In like manner, Easterly (2002) opines that the expectations of future debt relief, may encourage borrowers to the up excessive amounts of new loans, believing that the debt will be forgiven when the debtor is unable to repay the debt.

The direct and indirect effect debt theory: The Direct Effect Theory (DEDT) states that debt may adversely influence economic growth even if it has little effect on investment. This effect is channelled directly though deterioration of the capital production in the face of debt (Fosu, 1996). Externally borrowed money could be used for current and future consumption. In this case, the use of loans for current consumption does not alter capital formation greatly. Furthermore, for loans to have impact on future consumption, it requires productive investment particularly long term. This changes investment mix and in an attempt to use borrowed money to service existing debt or finance current account deficits, the investment funds would be decreased owing to the Foreign exchange restrictions. This type of constraints would cause short term investment projects like short term export generating goods and services, instead of investing on infrastructure development. As such, large debt in the face of relatively low ability to pay may reduce productive investment mix. In this situation, there will fall in investment mix even in the presence of stable savings and output will be affected adversely. Indirect Effect Debt Theory (IEDT) is based on the effects of debt on growth through investment. The theory postulates that higher indebtedness is detrimental to future output and reduces the incentive to save and invest because it acts as a tax (Fosu, 1996). This theory opines that there is an indirect linkage from external debt to output level. Given the initial capital requirement, the theory shows that the accumulation of external debt outside a certain level may deter economic growth. In addition, this theory maintains that the rate of debt payment obligation influences output. Thus, if a country's indebtedness surpasses the ability to pay, the expected future growth rate may likely fall (Karagol, 2002).

The review of empirical literature: Many scholarly studies have been carried out on the effect of external debt on economic growth in Nigeria and other parts of the world. But in all these studies, there have been mix findings both in developing, emerging and developed countries. While some of these studies supported a positive relationship between external debt and economic growth (Deshpande, 1997; Frimpong and Oteng-Abayie, 2006; Amoateng and Amoako, 1996; Bakar and Hassan, 2008; Sulaiman and Azeez, 2012), majority of others studies in Asia and Africa but Nigeria in particular evidenced a negative relationship between them (e.g., Hassan et al., 2015; Zouhaier and Fatma, 2014; Zafar et al., 2015; Savvides et al., 1996; Audu, 2004; Ajayi, 1991; Ajayi and Khan, 2000; Degefe, 1992; Fosu, 1999; Ezeabasili et al., 2011; Ayadi and Ayadi, 2008). However, Savvides (1992), Borensztein (1991), Elbadawi et al. (1996), Cameroon et al. (2001), Deshpande (1997) and Bauerfreund (1989) studies show that external debt overhang have significant and negative effect on investment rates. Also, Cunningham (1993) shifting his study on sixteen heavily indebted selected nations, found that the growth in debt burden affect economic growth negatively while a similar study carried out by Essien and Onwioduokit, Iyoha (1999) in Nigeria also reveals that increase in debt stock and burden has been the root cause of Nigeria's sluggish growth as well as depressed investment resulting to slow economic growth rate.

Contrary to these findings, Cohen (1993) investigation on a sample of 81 developing countries over three sub periods hold that the amount of debt does not justify the reduction of investment especially in highly organised developing countries. This finding is consistent with the works of Afxentiou and Serletis (1996) on a sample of 55 severely indebted countries which affirm no causal relationship existing between debt and per capital income growth. Therefore, investigating the influence of debt service on economic performance, Karagol (2002) found that external debt service negatively relate to long-run economic growth. Also, in Pakistan, Hameed et al. (2008) results reveals that an increase in external debt service causes decline in private investment in long run. In like manner, Atique and Malik (2012) examine the external debt impact on the economic growth and concluded that the amount of external debt slows down economic growth of the country. In addition, study on 20 developing countries by Green and Villaneva (1991) shows that the ratio of debt to GDP and debt service ratio significantly and negatively affects private investment. Study in some Latin American and Caribbean countries, found that decreasing amount of external debt levels promotes higher growth rates (Alfredo and Francisco, 2004).

Alternatively, Lora and Olivera (2006) outcome on testing the crowding out effect of public debt on social services, shows the effect to be driven by debt stock other than debt service. Therefore, they argued that multilateral organizational loan do not improve the undesirable consequences of debt on social expenditures. Thus, according to Dessy and Vencatachellum (2007), recognising the findings of Lora and Olivera (2006) results for Africa mean that, beneficiary of debt relief 
should have increased their expenditure in the social sector. Amoateng and Amoako (1996) investigation on the relationship between external debt and growth for 35 African countries using Granger causality test show a unidirectional and positive causal relation between debt service and economic growth. Furthermore, Korkmaz (2015) analysis of external debt and economic growth nexus in Turkey's economic performance shows a unidirectional causality running from economic growth. Hence, the existence of debt Laffer and non-linear effect of external debt on economic growth was observed in Nigeria in a study by Osinubi et al. (2006). Thus, they also confirm that countries that are heavily indebted in sub-Saharan Africa need to develop strategies for debt reduction to avoid severe and negative impact of high debt stock and associated crushing debt service burden on economic growth.

In addition, a study on the nexus between external debt and growth in Iran conducted by Safdari and Mehrizi (2011) reveals that the external is negatively related to gross domestic product. Also, Qayyum and Haider (2012) using annual data that span the period 1984-2008, investigates a panel of 60 developing countries. The empirical findings suggest that external debt has negative impact on the output growth. Contrary to these findings, Uzun et al. (2012) found that debt is positively related to growth rate of the countries in long run. Further evidence show a strong relationship between GDP per capita growth rate and external debt in the transition countries. Also, in Bangladesh while Shah and Pervin (2012) study found long run significant positive effects of external public debt stock on economic growth with no significant effect in the short run, Rahman et al. (2012) found bidirectional causality between economic growth and external debt. In an attempt to trace the relationship between external debt and economic of Malawi, Tehereni et al. (2013) found an insignificant and negative relationship between Foreign debt and growth. Though by Jordan and Abdelhadi findings show a positive and significant relationship between external debt and economic growth. Other studies in Indonesia, EAC member countries (Azam et al., 2013; Babu et al., 2014) also shows external debt has a negative impact on economic growth.

The review of SAP and external debt crisis in Africa: Overtime many African countries have been on course of economic planning. This has brought to bear many economic reforms in the system. However, this section discussed SAP policy reforms that were initiated as a result of debt crisis that had knocked many developing countries even before 1980 s. In this regard, we deliberate on the evaluation of the reform in Africa and then narrow it down to Nigeria, accessing the economy before, during and after the SAP initiated in Nigeria in 1986. To enhance the understanding of the idea, we summary each periods such as; Pre-SAP (1962-1985) era, the SAP (1986-1991)era, Post-SAP (1997-1998) era and the Democratic (1999-2015) era as shown below as it relate to Nigeria.

\section{Origin of external dept in Africa; Summary of historical} overview: In developing countries, especially, Africa, according to Jauch (2012), debt crisis traces it origin as far back as early $1970 \mathrm{~s}$, the time oil producing countries (OPEC members) hiked oil price for the purpose of making more gain. Most of the gains realized from the increase in oil price were invested with banks in developed countries. In turn, the same money deposited with the banks was given in terms of loan to African and other developing countries to finance the acquisition of products from their developed counterpart. During this lending saga, enormous amounts were borrowed, especially by political class which often time was wasted in money on luxuries or stolen by corruptions inherent in the system. Though, during this period, the loans were given at a very low interest rate which was changed by the USA in early 1980 's because of the attempt to control inflation. In like manner, European banks followed suit and consequently, the debt crisis emerged and all the developing countries-Africa in particular defaulted and were embarked on a new loans to offset the interest. This resulted to total debt of about US\$567 billion in 1980 which increased to US\$1 419 billion in 1992 due to the high interest rates for developing countries. To avoid bankruptcy, these countries were forced into taken new loan.

Since, 1980 s to date, some African countries have been struggling to repay the accumulated debt while others have succeeded in paying back their initial loan due to debt cancellation agreement. Though, many analysts viewed this practice as a mean of transferring wealth from African to their developed counterpart and that is why Francois Mitterand, the former French President admitted that irrespective of the amount spent on bilateral and multilateral aid, flow of capital from African countries to their developed counterparts is far much greater than the aid received from them. Regardless of the effort to offset the debt, many of the African countries (e.g., Nigeria; Fig. 1) are highly indebted with a continuous dependency on external loans thereby creating an avenue for IMF and World Bank to come as debt rescuers. These international organisations were at first sight seen as aid donor to assist the development of African countries but invariable that seems to be a 
pretentious character with a hidden agenda of impoverishing the African countries by making sure that they receive new loan and continue the payment of the old debt. Though, many analysts do not perceived IMF and World Bank as liberal economists because of their influence over many countries. But this continues to a point that Structural Adjustment Programmes (SAP) as initiated by IMF and World Bank became a pre-condition for African and other developing countries to be declared credit worthy. Thus, during this period (1980s), SAP became the only policy option for almost all the African countries and since, then many analysts have lost in scepticism on the impact of SAP on the economies of these countries.

Contrary to the SAP successes claim by IMF and World Bank, obviously it has failed to achieve the articulated fundamental goals in many African and developing countries like, liberalisation, privatisation of public service and companies, de-regulations of labour relations and cutting social safety nets and improving competitiveness. In view of these goals, it was believed that the elimination of protective tariffs will make domestic industries in these countries more competitive thereby creating more wealth and development. But overtimes, the acclaimed wealth and development have not been created other than the embattled domestic manufacturing collapse, resulting to increased demand on imported consumers goods due to poor domestic production and consequently consistent increase in external debt burden.

Pre -SAP era (1962-1985): During the pre-SAP era (i.e., 1962-1985), ${ }^{a} 678.8$ was the initial amount for national economic planning to accelerate economic growth and improve the standard of living of the population in Nigeria. Out of this amount, $50 \%$ of the amount originated from Foreign source. During this era, the Nigerian economic performance was impressive than the recorded performance before the independence period even in the face of atmosphere of political turmoil. Within this era, in the first development plan, the average growth rate was $5.1 \%$, followed by $8.2 \%$ recorded in the second face of plan but with $3.2 \%$ fall in third face of the plan, resulting to $5.0 \%$ growth rate in that era. During this period, capital formation rose from an average of 14.1-26.7\% under the first and third plan, respectively indicating economic improvement.

SAP era (1986-1991): In 1986, IMF-World Bank structural adjustment programmes was born with the view of effective restructuring of the consumption and production and distortion of over dependency on crude oil and importations of consumer and producer good
(Anyanwu, 1997). Though, the programme was designed to transform the Nigerian economy and curtailing external imbalance with a restrictive monetary policy (Yesufu, 1996; Adeyemi (1996), so as to sustain external debt service, domestic savings and investment. Between these periods, the performance of the economic seems to improve further in terms of sectoral and overall growth rates. Thus, resulting to development in agriculture, financial and oil sectors and the alteration of overvalued domestic currency (Naira) assumed to be the main cause of increased importation. However, the amazing aspect of this fact remains that as the government revenue increases within this era, the debt burden surge from US\$19.5 billion in 1985 to US\$34.4 billion in 1991 owing to consistent increased in unpaid interest charges, new borrowings, interest rates and exchange rates appreciation of Euro and Japanese currencies as against US dollar. Thus, this led to increase in the external debt burden and debt service ratio which stood at $16.3 \%$ between 1982 and 1985 and suddenly increased to $26.7 \%$ on average between 1986 and 1994. Hence, make a fuss of greater strain on the earnings of Foreign exchange, indicating the failure of debt rescheduling programmes by the London and Paris club creditors (Adepoju et al., 2007). According to Anyanwu et al. (1997) and Adeyemi (1996), SAP programmes exposed Nigeria into endemic inflation, high unemployment, low capacity utilization, Foreign exchange shortage along with greater height of inefficiency in resources mobilisation.

Post-SAP era (1997-1998): In 1995, the country had balance of payment deficits due to severe pressure from external sector which led to further accretion of external debt service due to the country's inability to repay her debt obligations. Owing to this, in 1997, there was a downward allocation for debt serving peg in addition with many other options exploited with no much effect on the economic performance of the nation. To this, as a matter of policy urgency, the government implemented a policy that discouraged any external loan except on a concessionary grounds on a condition that it will be used for export-increasing or import-decreasing economic activities that serve as an incentive to economic growth.

Democratic era (1999-2006): In 1999, Nigeria transformed to a democratic nation but remain strongly indebted with about US $\$ 28.77$ billion debt also similar to 1988 debt. During this period there was embargo lift on Foreign loans but that did not translate to the demand for new loan considering high amount of un-serviced loan owed to Paris club and arrears on post cut-off date debt. In spite of constraints on external borrowing within the 
period, the sum of US\$1.5 billion was reserved for the service of 2000 debt while continuous arrangement was made to see continuous negotiation on debt reduction. After a while concessionary borrowing, especially from World Bank took the heel for the promotion of social and infrastructural projects (Obadan, 2000). But to the greatest dismay, in 2004, there a recorded US $\$ 31.0$ billion worth of debt overhang which deterred private investment and economic growth. Therefore, considering debt overhang, the government authorities in its budget proposed to service her external in such a manner it will not hurt growth and this brought to bear the initiation and the implementation of National Economic Empowerment Development Strategy (NEEDS) reforms in 2004 aimed at poverty reduction (Obadan, 2004). Between 2004 and 2006 , real GDP growth rate averaged $6.6 \%$ as against the annual target of $6.0 \%$. In addition, there was phenomenal increased inflow of FDI and portfolio investment, especially in the telecom and banking industry.

\section{MATERIALS AND METHODS}

Theoretical framework: This study is based on the postulates of dual-gap model by Chenery and Strout (1996) which believed that external borrowing is the cure to insufficient savings to finance investment. They maintain that sustainable economic growth requires a given level of savings and investment, especially where savings is not sufficient. Therefore, an economy requires domestic savings to ensure growth. Invariably, this implies that external finance could leads to the accumulation of external debt to facilitate economic growth. Thus, Dual-gap framework states that excess investment expenditure over domestic savings is equivalent to the surplus of imports over exports (Chenery and Strout, 1996). This can be seen in Eq. 1 assuming equilibrium of the identities hold.

$$
\mathrm{S}-\mathrm{I}=\mathrm{X}-\mathrm{M}
$$

Where:

$$
\begin{aligned}
& \mathrm{S}=\text { Savings } \\
& \mathrm{I}=\text { Investment } \\
& \mathrm{M}=\text { Import } \\
& \mathrm{X}=\text { Export }
\end{aligned}
$$

This shows that the domestic resource gap (S-I) is equal to Foreign exchange gap (X-M). Hence, an excess of import over export implies an excess of resources used by an economy over resources generated by it. This therefore implies that the need for Foreign borrowing is determined overtime by the rate of investment in relation to domestic savings.
Model specification: The model explores a linear relationship linear regression model to estimates the relation between growth and external debt. The study also investigate the extent to which SAP has achieved the desired objectives in terms of economic growth during the pre-SAP (1970-1985) and post-SAP (1986-2010). The relevance of the policy implications are in view of the contributions of findings to rethinking SAP in Nigeria. This knowledge could serve as guide to the government authorities in the pursuance future developmental programmes. The functional form of the model is specified as:

$$
\text { Grgdp }=\mathrm{f}(\text { Exdbt, Fdi, Tpn, Ms, Rir, Ts, Sap })
$$

Where:

Grgdp $=$ Growth rate of real gross domestic product

Exdbt $=$ External debt

Fdi = Foreign direct investment

Tpn $\quad=$ Trade openness

Ms = Money supply

Rir $=$ Real interest rate

Ts $=$ Total savings

Sap = Dummy for Structural adjustment programme taking the value 0 for pre-sap period and 1 if otherwise

Moreover, the mathematical form of the model is specified as:

$$
\begin{aligned}
& \operatorname{Grgdp}_{\mathrm{t}}=\mathrm{a}_{0}+\mathrm{a}_{1} \operatorname{Exdbt}_{\mathrm{t}-\mathrm{i}} \mathrm{a}_{2} \mathrm{Fdi}_{\mathrm{t}-\mathrm{i}}+\mathrm{a}_{3} \mathrm{Tpn}_{\mathrm{t}-\mathrm{i}}+\mathrm{a}_{4} \mathrm{Ms}_{\mathrm{t}-\mathrm{i}}+ \\
& \mathrm{a}_{5} \operatorname{Rir}_{\mathrm{t}-\mathrm{i}}+\mathrm{a}_{6} \mathrm{Ts}_{\mathrm{t}-\mathrm{i}}+\mathrm{a}_{7} \operatorname{Sap}_{\mathrm{t}-\mathrm{i}}
\end{aligned}
$$

All the variables remained as define above. $\alpha_{0}$ is the intercept term while $\alpha_{1, \ldots, 7}$ is the relative slope coefficients and partial elasticity's of the parameters. However, the econometric form of the model is specified as:

$$
\begin{aligned}
& \operatorname{Grgdp}_{\mathrm{t}}=\mathrm{a}_{0}+\mathrm{a}_{1} \operatorname{Exdbt}_{\mathrm{t}-\mathrm{i}} \mathrm{a}_{2} \mathrm{Fdi}_{\mathrm{t}-\mathrm{i}}+\mathrm{a}_{3} \operatorname{Tpn}_{\mathrm{t}-\mathrm{i}}+\mathrm{a}_{4} \mathrm{Ms}_{\mathrm{t}-\mathrm{i}}+ \\
& \mathrm{a}_{5} \operatorname{Rir}_{\mathrm{t}-\mathrm{i}}+\mathrm{a}_{6} \operatorname{Ts}_{\mathrm{t}-\mathrm{i}}+\mathrm{a}_{7} \operatorname{Sap}_{\mathrm{t}-\mathrm{i}}+\mu_{\mathrm{t}}
\end{aligned}
$$

$\mu_{\mathrm{t}}$ is the stochastic error term.

Data sources and transformations: Time series data covering the period 1970-2015 were sourced from Central Bank of Nigeria (CBN) Statistical Bulletin (2015) and World Development Indicators (2015). To scale the variables, some of the data used were transformed to their natural logarithm. This is to give the data equal weight and to enhance the interpretation. 
The Soc. Sci., 14 (2): 55-67, 2019

\section{RESULTS AND DISCUSSION}

Unit root test: The study subjected all its variables to unit root tests. For this purpose, the Augmented Dickey-Fuller unit root test was used. A variable is stationary if the absolute $\mathrm{ADF}$ value $(|\tau|)$ is greater than any of the absolute Mackinnon tau critical values. The summary results of the unit root tests are shown in Table 1.

From the results as shown in Table 1, all the variables are integrated of order one. Thus, suggesting that the variables are stationary at first difference at $5 \%$ level of significance. Moreover, from the results $(/-2.246 /</-2.958 /)$ of the cointegration test conducted, it was observed that the variables are not cointegrated at $5 \%$ level of significance. This implies that they do not have long run equilibrium relationship among them. Hence, the estimation of error correction model becomes irrelevant.

Analysis estimated results: Table 2 present the estimated results of the model given in Eq. 4. But before the estimation, we subject the model to other OLS assumptions such as; heteroschedasticity, Multicollinearity, normality of error and autocorrelation. From the outcome, all the assumptions of OLS regression are satisfied.

The estimated results on Table 2 show a positive and significant relationship between external debt (LnExdbt) and economic growth in Nigeria at 5\% level of significance. This conforms to the a priori expectation as given by the Keynesian theory which postulates that increase in external debt will result in increase in economic growth if invested in public capital goods. From the results, $1 \%$ increase in external debt brought about $23.93 \%$ increases in economic growth, cetris paribus. This increase in output growth may be spurred by increase investment in key public capital projects which in most cases complement private capital (Aschauer, 1989). In addition, this findings contradict the findings of Hassan et al. (2015), Zouhaier and Fatma (2014), Zafar et al. (2015), Savvides et al. (1996), Ndungu 1998), Ayadi and Ayadi (2008), Audu (2004), Ajayi (1991), Degefe (1992) and Ezeabasili et al. (2011). Also, this finding also concurs with the dual gap theory which considered external finance as the panacea to attained sustainable growth. In addition, we also observed total saving (LnTs) to be positive and significant determinant of economic growth. Hence, a percentage increase in LnTs increases in economic growth by $18.7 \%$. Further evidence also shows that Foreign direct investment (LnFdi) is positively related to economic growth, indicating a corresponding increase economic growth as LnFdi increases. Thus, a percentage increase in LnFdi
Table 1: The summary of unit root tests results

\begin{tabular}{lcc}
\hline Variables & ADF value & Order of integration \\
\hline LnGrgdp & -5.792 & $1(1)$ \\
LnExdbt & -4.009 & $\mathrm{I}(1)$ \\
LnTpn & -9.440 & $\mathrm{I}(1)$ \\
LnMs & -4.390 & $1(1)$ \\
Rir & -9.898 & $1(1)$ \\
LnFdi & -8.153 & $1(1)$ \\
LnTs & -4.415 & $1(1)$ \\
\hline
\end{tabular}

Table 2: The estimated results

\begin{tabular}{lccc}
\hline Variables & Coefficient & Standard error & t-values \\
\hline Constant & 6.06676 & 1.03158 & 5.88 \\
LnExdbt & 0.23932 & 0.04259 & 5.61 \\
LnTpn & 0.21274 & 0.32562 & 0.65 \\
LnMs & 0.10081 & 0.03594 & 2.80 \\
Rir & -0.07571 & 0.01760 & -4.30 \\
LnFdi & 0.37289 & 0.03024 & 12.33 \\
LnTs & 0.18777 & 0.02234 & 8.40 \\
Sap & 0.24953 & 0.38081 & 0.66 \\
\hline
\end{tabular}

according to the results causes about $37.2 \%$ increase in economic growth. Therefore, there is the need to promote friendly business environment to encourage the inflow of FDI. This may create more job opportunities and in turn help to reduce high rate of poverty in the country.

Reveal real interest rate (Rir) has been expressed as a major determinant of economic growth through its effect on investment. This ascertained by the significant and negative relationship observed from the findings of the study. From the results, a percentage increase in real interest rate, result to $7.6 \%$ decrease in economic growth, which implies that policies promoting low interest rate will encourage borrowing which is required for productive investments and help in the realization of sustained economic growth. Invariably, investment could be discouraged by increasing interest rates. In like manner, the removal of trade restrictions (trades opennessLnTpn) has no significant effect on economic growth. Though, we observed a positive relationship between LnTpn and economic growth at 5\% significant level. This result shows that a liberal trade policy would be good for the growth of the economy. Money supply (LnMs) is positive and significant determinant of economic growth. This shows that increase in money supply may speed up level of economic activities. Hence, given the period of the study, a percentage increase in the supply of money has a corresponding increase of about $10.8 \%$ in economic growth. Further inquiries on the nexus between Structural Adjustment Programmes (SAP) and economic growth show a positive and significant relationship. But to investigate the extent of economic growth during pre-SAP (1970-1985) and post-SAP (1986-2010) era, semi-elasticity for a dummy regressor was obtained following the techniques suggested by Halvorson and Palmquist. This is done by taking the antilog (to base e) of the estimated dummy coefficient $\left(\mathrm{e}^{0.2495327}=1.283256\right)$ and 
subtracting 1 from it. Thereafter, we multiply the difference by 100 . The outcome (semi-elasticity for a dummy regressor $=28.34255$ ) shows that growth in RGDP increased by $28.3 \%$ in the post-SAP era more than the pre-SAP era. This means that economic policies from 1986 till 2015 have impacted on the economic performance of Nigeria by $28.3 \%$ more than the era when it was not in existence.

\section{CONCLUSION}

This study examined the impact of external debt on economic growth in Nigeria. This was extended to estimate the extent of the impact of Structural Adjustment Programmes (SAP) during pre-SAP (1970-1985) and post-SAP (1986-2010) era. The results confirmed a positive and significant impact of external debt (LnExdbt) on economic growth (Grgdp). This finding supports the research of Deshpande (1997), Frimpong and OtengAbayie (2006), Amoateng and Amoako (1996), Bakar and Hassan (2008), Sulaiman and Azeez (2012) and Cohen (1993). Though, many researchers like Savvides (1992), Cunningham (1993), Alfredo and Franscico (2004) found a negative relationship running from external debt to growth. In addition, further inquiries show that growth in RGDP increased by $28.3 \%$ in the post-SAP era more than the pre-SAP era. Therefore, from the estimated regression results, we conclude that external debt (LnExdbt) is positively and significantly impacts on economic growth and that growth rate of RGDP increased by $28.3 \%$ during the post-SAP era.

\section{RECOMMENDATIONS}

Consequently, we suggest the need for adequate resources mobilisation in Nigeria to promote production and to meet debt service obligations on time. This will enhance easy access to access to external resources. External debt, if not sustainable, may adversely affect the economic growth. Hence, for the sustainability, we urge the government authorities to invest more in infrastructural development in other to drive the private sector as the engine of economic growth. Therefore, directing the external funds to a project that could help in creating new opportunities for investment and attract more investors to their countries should be regarded as the key objective. Hence, external debt should only be sourced for high priority projects. More so, a sound analysis of the economic and social profitability of all debt-financed projects must be carried out to ensure that the returns generated will be in excess of the interest and capital repayment. Finally, the use of externally borrowed funds for government projects must be closely monitored in order to make sure they are invested in high capital projects.

\section{REFERENCES}

Abdelhadi, S.A., 2013. External debt and economic growth: Case of Jordan (1990-2011). J. Econ. Sustainable Dev., 4: 26-33.

Abubakar, S., 2008. External debt and Nigerian economic development: An empirical investigation. Master Thesis, Department of Accounting, Ahmadu Bello University, Zaria, Nigeria.

Adam, J.A. and A.S. Bankole, 2000. The macroeconomics of fiscal deficits in Nigeria. Niger. J. Econ. Soc. Stud., 42: $263-290$.

Adegbite, E.O., F.S. Ayadi and O.F. Ayadi, 2008. The impact of Nigeria's external debt on economic development. Intl. J. Emerging Markets, 3: 285-301.

Adepoju, A.A., A.S. Salau and A.E. Obayelu, 2007. The effects of external debt management on sustainable economic growth and development: Lessons from Nigeria. Masters Thesis, University of Ibadan and Ladoke Akintola University of Technology, Kingston, Jamaica.

Adesola, W.L., 2009. Debt service and economic-growth in Nigeria. Global J. Soc. Sci., 8: 1-11.

Afxentiou, P.C. and A. Serletis, 1996. Foreign indebtedness in low- and middle-income developing countries. Soc. Econ. Stud., 45: 133-159.

Ajayi, S.I. and M.S. Khan, 2000. External Debt and Capital Flight in Sub-Saharan Africa. International Monetary Fund Publication, Washington, DC., USA., Pages: 321 .

Ajayi, S.I., 1991. Macroeconomic Approach to External Debt, the Case of Nigeria. Vol. 8, Initiatives Publishers, Africa, ISBN:9789966420312, Pages: 66.

Amoateng, K. and B. Amoako-Adu, 1996. Economic growth, export and external debt causality: The case of African countries. Appl. Econ., 28: 21-27.

Anonymous, 2015. World development indicators. World B ank, Washington, U S A. http://datatopics.worldbank.org/world-developmen t-indicators/

Ariyo, A., 1996. Budget Deficits in Nigeria, 1974-1993: A Behavioural Perspective. In: Economic Reform and Macroeconomics Management in Nigeria, Ariyo, A. (Ed.). S.N. Publishing Company, Sezen Aksu, Turkey, pp: 263-263.

Arnone, M., L. Bandiera and A.F. Presbitero, 2005. External debt sustainability: Theory and empirical evidence. Catholic Univ. Piacenza Econ., 33: 1-47. 
Aschauer, D.A., 1989. Is public expenditure productive? J. Monetary Econ., 23: 177-200.

Atique, R. and K. Malik, 2012. Impact of domestic and external debt on the economic growth of Pakistan. World Appl. Sci. J., 20: 120-129.

Audu, I., 2004. The impact of external debt on economic growth and public investment: The case of Nigeria. African Institute for Economic Development and Planning (IDEP), Dakar, Senegal. http://invenio. unidep.org/invenio//record $/ 17804 /$ files/external $\% 20$ debt $\% 20$ nigeria.pdf

Ayadi, F.S. and F.O. Ayadi, 2008. The impact of external debt on economic growth: A comparative study of Nigeria and South Africa. J. Sustainable Dev. Afr., 10: 234-264.

Azam, M., C. Emirullah, A.Q. Khan and A.C. Prabharker, 2013. The role of external debt in economic growth of Indonesia-A blessing or burden. World Appl. Sci. J., 25: $1150-1157$.

Babu, J.O., S. Kiprop, A.M. Kalio and M. Gisore, 2014. External debt and economic growth in the East Africa community. Afr. J. Bus. Manage., 8: 1011-1018.

Bakar, N.A.A. and S. Hassan, 2008. Empirical evaluation on external debt of Malaysia. Int. Bus. Econ. Res. J., 7: 95-108.

Bauerfreund, O., 1989. External debt and economic growth: A computable general equilibrium case study of Turkey 1985-1986. Ph.D. Thesis, Duke University, Dubai, UAE.

Bhatia, H.L., 2006. Public Finance. VRINDA Publications Ltd., New Delhi, India,.

Borensztein, E., 1991. Debt overhang, debt reduction and investment: The case of the Philippines. IMF. Working Paper, 1: 1-27.

Bulow, J. and K. Rogoff, 1990. Cleaning up third world debt without getting taken to the cleaners. J. Econ. Perspect., 4: 31-42.

CBN., 2015. Annual statistical bulletin. Central Bank of Nigeria, Nigeria. http:/www.cbn.gov.ng/documents/ statbulletin.asp

Cassimon, D., R. Renard and K. Verbeke, 2008. Assessing debt-to-health swaps. Lancet, 371: 473-473.

Checherita, C. and P. Rother, 2010. The impact of high and growing government debt on economic growth: An empirical investigation for the Euro area. Master Thesis, European Central Bank, Frankfurt, Germany.

Chenery, H. and W. Strout, 1996. Foreign assistance and economic develop-development. Am. Econ. Rev., 66: 679-733.

Chowdhury, K., 1994. A structural analysis of external debt and economic growth: some evidence from selected countries in Asia and the Pacific. Appl. Econ., 26: 1121-1131.
Claessens, S. and I. Diwan, 1990. Investment incentives: New money, debt relief and the critical role of conditionality in the debt crisis. World Bank Econ. Rev., 4: 21-41.

Claessens, S., E. Detragiache, R. Kanbur and P. Wickham, 1996. Analytical Aspects of the Debt Problems of Heavily Indebted Poor Countries (No. 1618). World Bank Publications, Africa,.

Clements, B., R. Bhattarcharya and T.Q. Nguyen, 2003. External Debt, Public Investment and Growth in Low-Income Countries. IMF, Washington, DC., USA.,.

Cohen, D., 1993. Low investment and large LDC debt in the 1980's. Am. Econ. Rev., 83: 437-449.

Cordella, T., A. Ricci and R. Arranz, 2005. Debt Overhang or Debt Irrelevance? Revisiting the Debt-Growth Link. International Monetary Fund, Washington, DC., USA.,

Cunningham, R.T., 1993. The effects of debt burden on economic growth in heavily indebted developing nations. J. Econ. Dev., 18: 115-126.

Curutchet, A.S., 2005. Debt and economic growth in developing and industrial countries. MA Thesis, Department of Economics, Lund University, Lund, Sweden.

Degefe, B., 1992. Growth and Foreign Debt: The Ethiopian Experience: 1964-86. African Economic Research Consortium, Nairobi, Kenya,

Deshpande, A., 1997. The debt overhang and the disincentive to invest. J. Dev. Econ., 52: 169-187.

Dessy, S.E. and D. Vencatachellum, 2007. Debt relief and social services expenditure: The African experience, 1989-2003. Afr. Dev. Rev., 19: 200-216.

Easterly, W., 2002. How did heavily indebted poor countries become heavily indebted? Reviewing two decades of debt relief. World Dev., 30: 1677-1696.

Elbadawi, I., B. Ndudu and N. Ndungu, 1997. Debt Overhang and Economic Growth in Sub Saharan Africa. In: External Finance for Low Income Countries, Iqbal, Z. and K. Ravi (Eds.). IMF Institute, Washington, DC., USA., pp: 49-76.

Ellig, J., 2001. Internal markets and the theory of the firm. Managerial Decis. Econ., 22: 227-237.

Ezeabasili, V.N., H.O. Isu and J.N. Mojekwu, 2011. Nigeria's external debt and economic growth: An error correction approach. Intl. J. Bus. Manage., 6: 156-170.

Ezeabasili, V.N., H.O. Isu and J.N. Mojekwu, 2011. Nigeria's external debt and economic growth: An error correction approach. Intl. J. Bus. Manage., 6: 156-170. 
Ezike, J.E., and J.N. Mojekwu, 2011. The impact of external debt on macro-economic performance. Intl. J. Bus. Manage., 1: 1-12.

Fosu, A.K., 1996. The impact of external debt on economic growth in Sub-Saharan Africa. J. Econ. Dev., 21: 93-118.

Fosu, A.K., 1999. The external debt burden and economic growth in the 1980s: Evidence from Sub-Saharan Africa. Can. J. Dev. Stud., 20: 307-318.

Fosu, A.K., 2007. The external debt-servicing constraint and public expenditure composition: Evidence from African Countries. Master Thesis, UNU-WIDER, Katajanokanlaitur, Helsinki, Finland.

Frimpong, J.M. and E.F. Oteng-Abayie, 2006. The impact of external debt on economic growth in Ghana: A cointegration analysis. J. Sci. Technol., 26: 122-131.

Greene, J. and D. Villanueva, 1991. Private investment in developing countries: An empirical analysis. Staff Pap., 38: 33-58.

Gujarati, M.D., 2004. Basic Econometrics. 4th Edn., Tata McGraw-Hill Publishing Co. Ltd., New York, USA., ISBN-13: 9780070597938, Pages: 1002.

Hameed, A., H. Ashraf and M.A. Chaudhary, 2008. External debt and its impact on economic and business growth in Pakistan. Int. Res. J. Finance Econ., 20: 132-140.

Hassan, O.M., A. Sule and J. Abu, 2015. Implications of external debt on the Nigerian economy: Analysis of the dual gap theory. J. Econ. Sustainable Dev., 6: 238-248.

Iyoha, M.A., 1999. External debt and economic growth in Sub-Saharan African countries: An econometric study. Research Paper No.90, African Economic Research Consortium, Nairobi, Kenya.

Iyoha, M.A., 2000. The impact of external debt reduction on economic growth in Nigeria: Some simulation results. Niger. J. Econ. Soc. Stud., 42: 235-262.

Jauch H., 2012. How the IMF-World Bank and Structural Adjustment Program (SAP) destroyed Africa. News Rescue, Africa. http://newsrescue. com/how-the-imf-world-bank-and-structuraladjustment-programsap-destroyed-africa/\#axzz3Ihi FrD7R

Johansson, P., 2010. Debt relief, investment and growth. World Dev., 38: 1204-1216.

Karagol, E., 2002. The causality analysis of external debt service and GNP: The case of Turkey. Central Bank Rev., 1: 39-64.
Korkmaz, S.U.N.A., 2015. The relationship between external debt and economic growth in Turkey. Proceedings of the Second European Academic Research Conference on Global Business, Economics, Finance and Banking, July 3-5, 2015, EAR15Swiss, Zurich, Switzerland, ISBN: 978-1-63415-477-2, pp: 1-9.

Krugman, P., 1988. Financing vs. forgiving a debt overhang. J. Dev. Econ., 29: 253-268.

Lensink, R. and H. White, 1999. Is there an aid Laffer Curve?. Research Paper No.99/6, Centre for Research in Economic Development and International Trade, University of Nottingham, Nottingham, England. https://www.econstor.eu/bitstream/10419/81806/1/9 9-06.pdf

Lora, E. and M. Olivera, 2006. Public debt and social expenditure: Friends or foes?. Technical Report 563, Inter-American Development Bank, Washington DC., USA. https://papers.ssm.com/sol3/papers.cfm? abstract_id=905964

Obadan, M.I., 2000. External sector policy. Bullion Publ. CBN., 24: 39-43.

Obadan, M.I., 2004. Foreign Capital Flows and External Debt. Broadway Press, Lagos, Nigeria,

Ogunmuyiwa, M.S., 2011. Does external debt promote economic growth in Nigeria. Current Res. J. Econ. Theory, 3: 29-35.

Ojo, M.O., 1994. African Debt Burden in Historical Perspective. In: African Debt Burden and Economic Development, Onah, F.E. (Eds.)., Nigerian Economic Society, Nigeria, pp: 14-34.

Omoh, G. and E. Ujah, 2014. Nigeria sinks deeper into external debt. Vanguard Media Limited, Nigeria. https://www.vanguardngr.com/

Osinubi, T.S., R.O.S. Dauda and O.E. Olaleru, 2010. Budget deficits, external debt and economic growth in Nigeria. Singapore Econ. Rev., 55: 491-521.

Pattillo, C., H. Poirson and L. Ricci, 2002. External Debt and Growth. International Monetary Fund, Washington, DC., USA.

Poirson, M.H., M.L.A. Ricci and M.C.A. Pattillo, 2004. What are the Channels through which External Debt Affects Growth?. International Monetary Fund, Washington, USA.,.

Qayyum, U. and A. Haider, 2012. Foreign aid, external debt and economic growth nexus in low-income countries: The role of institutional quality. Pak. Dev. Rev., 51: 97-115.

Rahman, M.M., M.A. Bashar and S. Dey, 2012. External debt and gross domestic product in Bangladesh: A co-integration analysis. Manage. Res. Pract., 4: 28-36. 
Sachs, J., 1989. The Debt Overhang of Developing Countries. In: Debt, Stabilization and Development: Essays in Memory of Carlos Diaz-Alejandro. Findlay, R., G. Calvo, P. Kouri and J.B. de Macedo (Eds.). Blackwell, Oxford, pp: 80-102.

Safdari, M. and M.A. Mehrizi, 2011. External debt and economic growth in Iran. J. Econ. Intl. Finance, 3: 322-327.

Savvides, A., 1992. Investment slowdown in developing countries during the 1980s Debt overhang or foreign capital inflows. Kyklos, 45: 363-378.

Savvides, A., M. Kumar and K. McLambo, 1996. Determinants of private investment in Sub Saharan Africa: An empirical investigation. Master Thesis, International Monetary Fund, Washington, USA.

Shah, M. and S. Pervin, 2012. External public debt and economic growth: Empirical evidence from Bangladesh, 1974 to 2010 . Acad. Res. Intl., 3: 508-515.

Solow, R.M., 1956. A contribution to the theory of economic growth. Quart. J. Econ., 70: 65-94.

Sulaiman, L.A. and B.A. Azeez, 2012. Effect of external debt on economic growth of Nigeria. J. Econ. Sustainable Dev., 3: 71-79.
Tchereni, B.H.M., T.J. Sekhampu and R.F. Ndovi, 2013. The impact of foreign debt on economic growth in Malawi. Afr. Dev. Rev., 25: 85-90.

Uzun, A., C. Karakoy, B. Kabadayi and O.S. Emsen, 2012. The impacts of external debt on economic growth in transition economies. Chinese Bus. Rev., 11: 491-499.

World Bank, 1994. Nigeria: Structural adjustment programme; policies, implementation and impact. World Bank, New Jersey, USA.

World Bank, 2016. World development report. World Bank, Washington, USA.

Yesufu, T.M., 1996. The Nigerian economy: Growth without development. Bennin Soc. Ser. Afr. Univ., 1: 89-110.

Zafar, M., P.S.U. Sabri, M. Ilyas and S. Kousar, 2015. The impact of trade openness and external debt on economic growth: New evidence from South Asia, East Asia and Middle East. Sci. Intl. Lahore, 27: 509-516.

Zouhaier, H and M. Fatma, 2014. Debt and economic growth. Intl. J. Econ. Financial Issue, 4: 440-448. 